\title{
Notas cortas
}

\section{New records of pigmentary abnormalities in two species of birds in Cali, Colombia} Nuevos registros de anomalías pigmentarias en dos especies de aves en Cali, Colombia

\author{
Giovanni Cárdenas ${ }^{\oplus}$ Juan Camilo Franco ${ }^{\square}$
}

\begin{abstract}
We report two bird species with pigment anomalies, which were seen in Cali, Colombia in 2020. The individuals were, a female Shiny Cowbird (Molothrus bonariensis) with partial leucism, a female Ruddy Ground-Dove (Columbia talpacoti) with partial leucism and a young nestling of the same species, with albinism. The records reported here are the first of partial leucism and albinism for Columbia talpacoti and partial leucism for Molothrus bonariensis in Colombia.
\end{abstract}

Key words. Albinisms. Chromatic aberrations. Columbia talpacoti. Molothrus bonariensis. Partial leucism. White plumage.

\section{Resumen}

Reportamos dos especies de aves con anomalías en la pigmentación, que se observaron en Cali, Colombia, en 2020. Los individuos eran una hembra de chamón parásito (Molothrus bonariensis) con leucismo parcial, una hembra de tortolita común (Columbia talpacoti) con leucismo parcial y un polluelo de la misma especie, con albinismo. Estos registros son los primeros de leucismo parcial y albinismo para Columbia talpacoti y de leucismo parcial para Molothrus bonariensis en Colombia.

Palabras clave. Aberraciones cromáticas. Albinismo. Columbia talpacoti. Leucismo parcial. Molothrus bonariensis. Plumaje blanco. 


\section{Introduction}

Plumage color in birds is the result of a combination of pigments deposited in the feathers; the most common pigments are melanins, including eumelanin, which gives rise to black, pheomelanin, to brown, while the carotenoids produce yellow, orange and red colors (McGrawet al., 2004; van Grouw, 2006; Davis, 2007; Guay et al., 2012; van Grouw, 2013). In contrast to these colors, the shades of blue result from light scattering, due to structural properties, and the greens from a combination of pigments and structural properties of the feathers (McGrawet al., 2004; Guayet al., 2012). If for some reason pigment or structural components are not incorporated properly as the feathers grow, plumage aberrations will occur (Guayet al., 2012).

Various types of abnormalities have been described, which are based on the excess, decrease, defect or absence of pigments, mainly melanins (van Grouw, 2006; Davis, 2007; Rodríguez-Ruízet al., 2017). These are attributed to factors such as inbreeding, hybridization, nutritional deficiency, lack of exposure to sunlight and environmental contamination (Rodríguez-Ruízet al., 2017). Among the color aberrations that have a genetic basis, caused by mutations, are albinism and leucism (van Grouw, 2006).

Albinism is defined as the total absence of melanins, and albinos have completely white plumage, reddish to pale pink irises (consequence of blood circulation) and tarsi that are sometimes pale yellow (Rodríguez-Ruízet al., 2017). The individuals can present carotene, porphyrin and keratin pigments, but due to genetic mutations the pigment cells lack the enzyme tyrosinase and cannot produce melanin (Rodríguez-Ruízet al., 2017). Although it is one of the most frequently mentioned color mutations, it is one of the less frequently observed ones (especially in adult birds) in the field (van Grouw, 2006). The reason for the apparent scarcity of individuals with albinism is that the absence of melanin in the eyes makes them very sensitive to light and gives them poor depth of vision. It is reported that poor eyesight rather than white plumage make albinos vulnerable, and that most die shortly after fledging (van Grouw, 2013).

Leucism is caused by an inheritable recessive genetic mutation, which produces an error in the deposition of eumelanin and pheomelanin in the feathers (Rodríguez-Ruíz et al., 2017). It is probably the most common inherited color aberration in birds, and is mistakenly called albinism or "partial albinism" (van Grouw, 2006). In leucistic birds, the enzyme tyrosinase is normal and melanin production in melanoblasts is normal. However, melanin deposition in feather cells does not occur. As a result, more or less colorless (white) feathers appear randomly in any part of the plumage (van Grouw, 2006). The extent of white plumage can vary, from a few white feathers (partial leucism) to completely white plumage (total leucism). The skin is colorless for individuals in the latter category (van Grouw, 2013).

Partially leucistic birds may have normally colored bill and legs, depending on where the colorless spots are located, but all leucistic birds have normal eye coloration (van Grouw, 2013). Because leucistic individuals often have melanin in their eyes, they are not limited by reduced vision. However, depending on the extent of the color aberration, they may suffer some of the same effects as individuals with albinism (van Grouw, 2006). The environmentally induced forms of leucism may have other problems, such as malnutrition or disease, that could reduce survival and reproduction (Davis, 2007). Although partial leucism has been reported in numerous bird families, it tends to be more common in socially or community-breeding birds such as blackbirds (Icteridae) and sparrows (Passerellidae) (Davis, 2007). It is more common in small isolated populations than in large continuous populations, and more prevalent in cities and small towns than in rural areas (Sage 1963; Benschet al., 2000).

In this paper, we report three records of wild birds with pigment anomalies that were found in the urban area of Cali, Valle del Cauca-Colombia in 2020. These birds were a female Shiny Cowbird (Molothrus bonariensis) with partial leucism, a female Ruddy Ground-Dove (Columbina talpacoti) with partial leucism and a young nestling Ruddy Ground-Dove with albinism. These species both have wide distributions from the southern United States to Argentina and Chile. They are remarkably gregarious and feed mainly on the ground in open places, alone, in pairs, or more frequently in groups of various sizes. They are common to abundant in open fields, cultivated areas, pastures, gardens, populated areas and urban centers (Meyer \& Phelps, 1978; Hilty \& Brown, 1986; Ridgely \& Gwynne, 1989).

\section{Materials and methods}

The records were collected during a standardized monitoring of urban birds carried out in nine Colombian urban centers. The bird surveys were conducted for 
10 minutes between 06:00-09:00 or 15:00-18:00 hours in fixed radius $(50 \mathrm{~m})$ circular point-counts. All birds seen or heard during the time and space of each pointcount were recorded, and only individuals that were actively within the surveyed area were recorded. Monitoring took place daily from close proximity to data collectors' homes or nearby parks, due to the national preventive isolation decreed by the government during the months of May and September 2020, due to the COVID-19 pandemic. Our surveys were made in Cali, capital of the department of Valle del Cauca, in southwestern Colombia. The individuals were observed with binoculars and photographed when there was an opportunity to do so. To determine the type of chromatic aberration, the dichotomous key for the identification of cases of pigment abnormalities proposed by Rodríguez-Ruíz et al. (2017) was followed.

\section{Results}

The first sighting was recorded on May 15, 2020, at 06:40 hours. Three Shiny Cowbirds were observed in the Parque de Las Banderas ( $\left.3^{\circ} 25^{\prime} 52.4^{\prime \prime} \mathrm{N}-76^{\circ} 32^{\prime} 35.1^{\prime \prime} \mathrm{W}\right)$ (Figure 1). Two of the individuals were identified as males with their characteristic glossy black plumage. The third individual had the characteristic colored plumage of a female, but some feathers on the back, a pair of rectrices, and the abdomen were white, while the bill was light yellow. Both the irises and the tarsi had the typical black coloration. The odd coloration did not correspond to the plumage of a typical female of the species. After a few moments, one of the male Shiny Cowbirds mounted this individual, so it was assumed to be a mature female Shiny Cowbird, and not an immature individual.
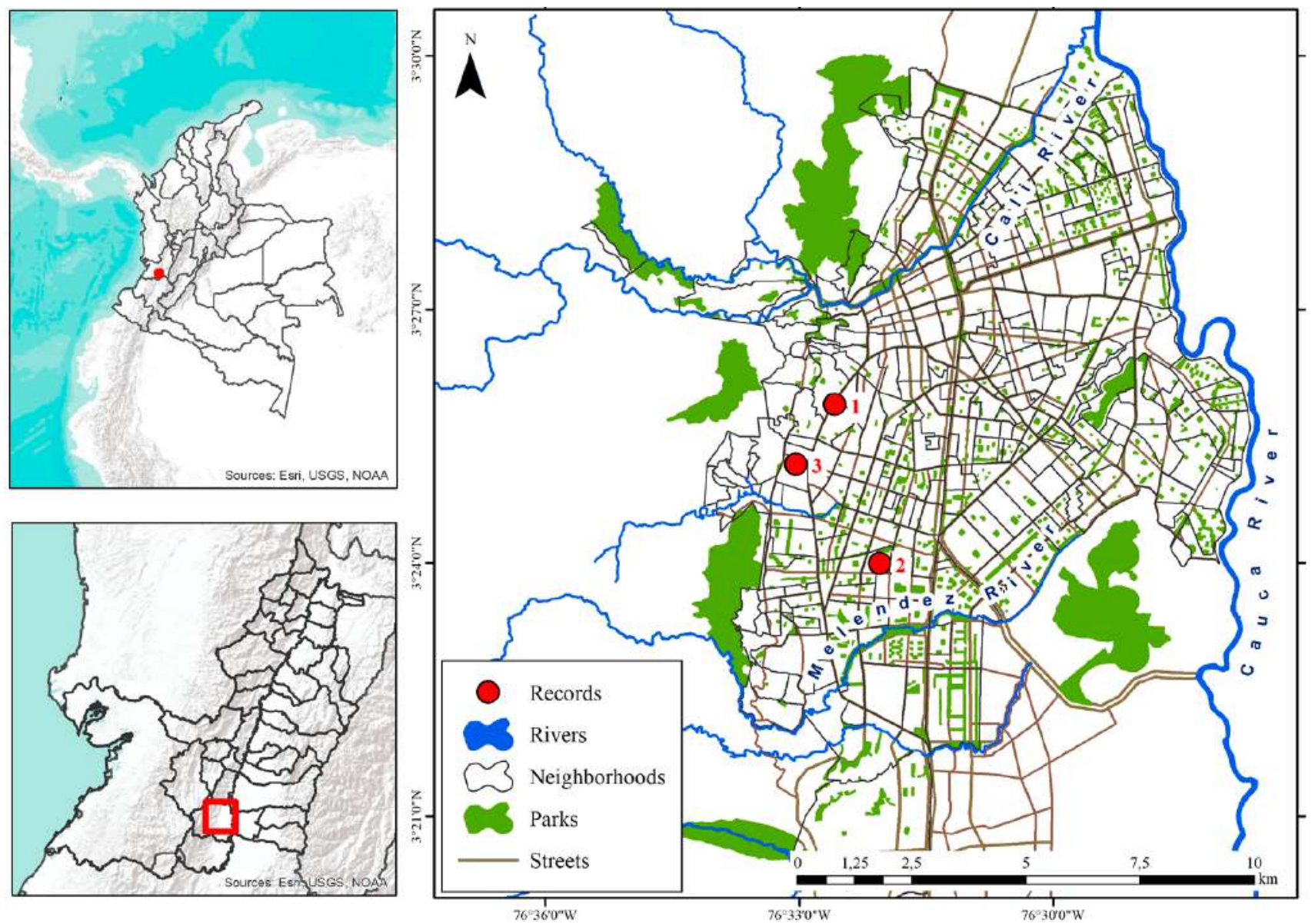

Figure 1. Locations within the urban area of Cali, Colombia of the sighting points of (1) a female Shiny Cowbird (Molothrus bonariensis), (2) a female Ruddy Ground-Dove (Columbina talpacoti) and (3) a young nestling Ruddy Ground-Dove, with pigmentary abnormalities. D. Eusse-González. 
These aberrations in the plumage suggested that the bird had a partial leucism aberration (Rodríguez-Ruízet al., 2017). Although a photographic record of the sighting was not made, observation and description of plumage coloration was posted on the eBird platform checklist.

The second sighting was recorded on May 25, 2020 at 17:00 hours. A female Ruddy Ground-Dove was observed in the neighborhood of Bosques del Limonar $\left(3^{\circ} 23^{\prime} 59.7^{\prime \prime} \mathrm{N}-76^{\circ} 32^{\prime} 03.2^{\prime \prime} \mathrm{W}\right)$ (Figure 1). The individual was feeding together with a female and a male of the same species, and no antagonistic interactions were observed with the other Ruddy Ground-Doves. The bird had normal plumage, except for some white feathers on the nape and back, which formed a well-defined and easy-to-see spot. The tarsi and irises had normal pigmentation (Figure 2). These characteristics in the coloration of the plumage suggest that this bird had a partial leucism aberration (Rodríguez-Ruíz et al., 2017).
This Ruddy Ground-Dove female was observed until mid-January 2021 at the same place.

The third sighting was recorded on September 8, 2020 at 17:50 hours. A young nestling Ruddy Ground-Dove was observed in the front yard of a residence in $\mathrm{El} \mathrm{Lido}$ neighborhood $\left(3^{\circ} 25^{\prime} 10.0^{\prime \prime} \mathrm{N}-76^{\circ} 33^{\prime} 02.7^{\prime \prime} \mathrm{W}\right)$ (Figure 1). The individual was a young that was found on the ground in good condition, but no parents were observed in the surroundings. It was decided to leave the bird where it was found, and the next morning the bird was gone. The young individual had white plumage over the entire body, including the covert and the flight feathers. The beak was pale yellow, without a trace of dark coloration; the tarsi were pale pink and the eyes had intense red irises, that was distinct from the normal dark red coloration (Figure 3). These characteristics in the coloration are typical for albino birds (Rodríguez-Ruízet al., 2017).
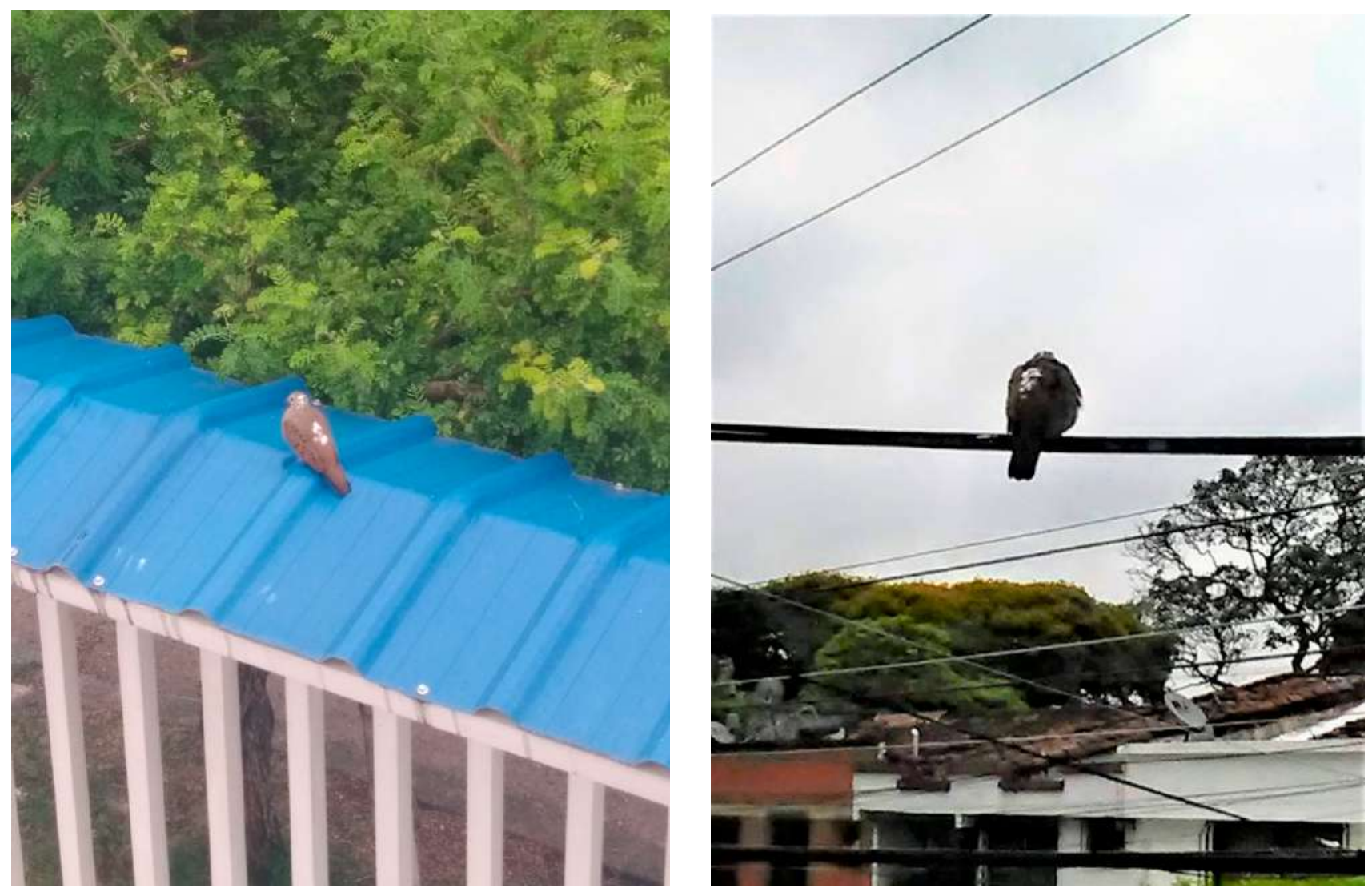

Figure 2. A female Ruddy Ground-Dove (Columbina talpacoti) with partial leucism, at Bosques del Limonar neighborhood in Cali, Colombia, May 25, 2020. G. Cárdenas. 

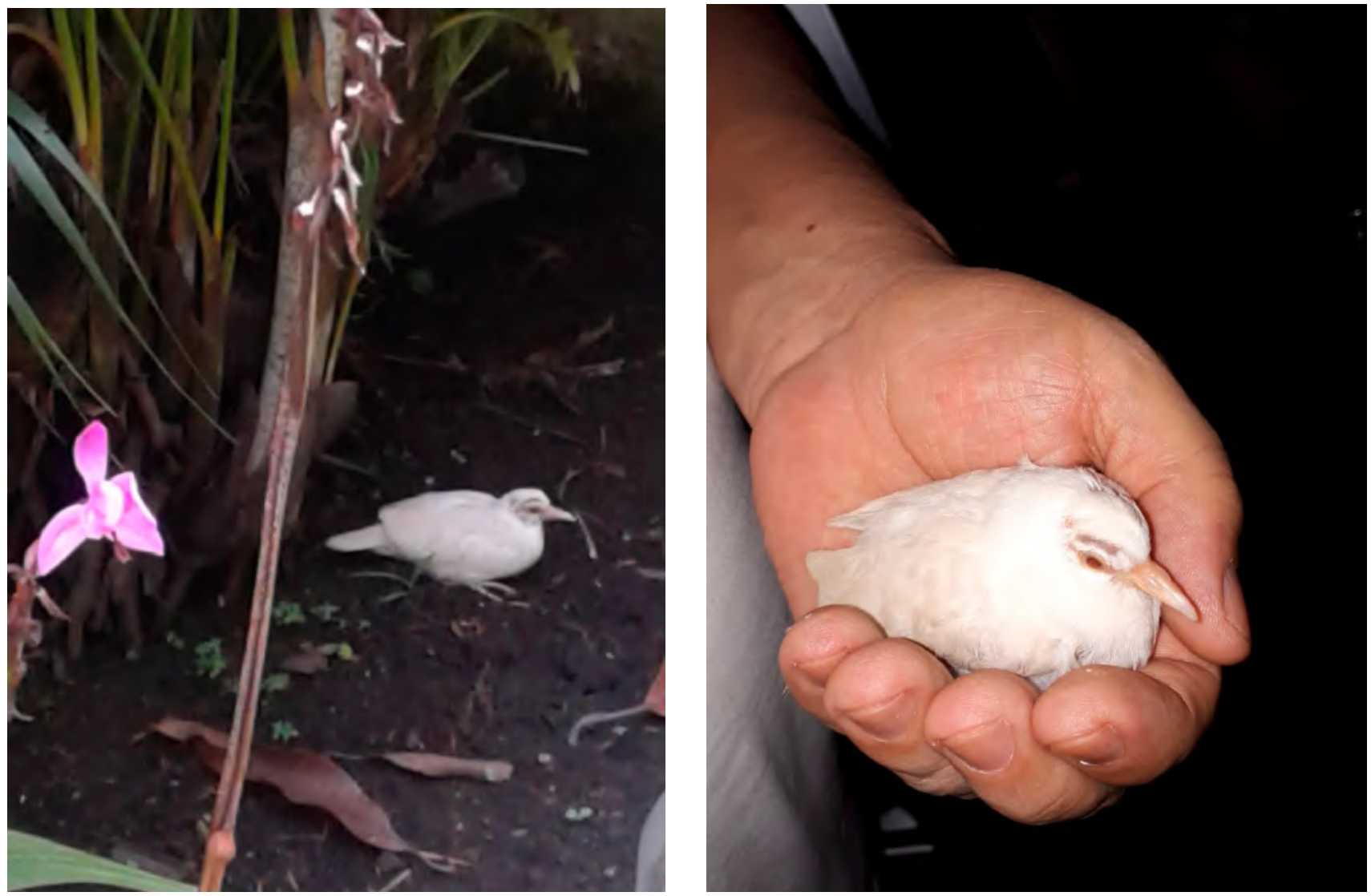

Figure 3. A young nestling Ruddy Ground-Dove (Columbina talpacoti) with albinism found in El Lido neighborhood in Cali, Colombia, September 8, 2020. I. C. Avila.

\section{Discussion}

Bird records in urban areas suggest that individuals with pigment abnormalities are easily detected if they are active during daytime, especially if they emit calls or vocalizations (Rodríguez-Ruízet al., 2017). Environmental factors such as malnutrition, toxin ingestion, injury, disease, parasites, shock, and old age can induce non-inherited forms of partial leucism (Davis 2007). Those factors may explain why aberrant plumages appear to be more common in urban areas, where the availability of food from different sources is greater, natural predators are fewer (Rodríguez-Ruíz et al., 2017) despite the pressure that other predators, such as cats, may exert on wild birds, and there is a greater possibility of being detected by observers (Aráoz et al., 2012) which influences the registration of aberrant individuals.

Different types of pigment abnormalities have been documented in the genus Molothrus. For example, in
Argentina the pastel dilution was reported for the Screaming Cowbird (M. rufoaxillaris) (Urcola, 2011), while in Mexico partial leucism (Hernández-Valdez et al., 2016) and in North America leucism (Gross, 1965), were reported for the Brown-Headed Cowbird (M. ater). For the Shiny Cowbird (M. bonariensis), albinism has been documented in Argentina (Urcola, 2011, Aráoz et al., 2012), partial leucism in Ecuador (Cadena-Ortiz et al., 2015), the ino aberration in Venezuela (Sainz-Borgo et al., 2016) and unspecified abnormal plumage in Chile (Fuentes \& González-Acuña, 2011). The record reported here constitutes first report of partial leucism for the Shiny Cowbird in Colombia.

Different types of pigment abnormalities have been documented in the genus Columbina. For example, in Ecuador partial leucism has been reported for the Ecuadorian Ground Dove (C. buckleyi) and total leucism in the Croaking Ground Dove (C. cruziana) (Cadena-Ortiz et al., 2015). In Chile, unspecified 
abnormal plumage for the Croaking Ground Dove was reported (Fuentes \& González-Acuña, 2011); in Argentina albinism was reported in the Picui Ground Dove (C. picui) (Urcola, 2011) and in Mexico partial leucism and melanism have been reported in the Inca Dove (C. inca) (Rodríguez-Ruiz et al., 2015, Rodríguez-Ruíz et al., 2017). For the Ruddy Ground-Dove (C. talpacoti), schizochroism has been documented in Brazil (Missagia et al., 2016), ino aberration in Venezuela (Sainz-Borgo et al., 2016), while in Colombia, leucism was reported (Yusti-Muñoz \& Velandia-Perilla, 2013). However, the photographs and the description provided by the latter authors suggest that the individual presented rather a reddish schizochroism aberration, according to the dichotomous key proposed by Rodríguez-Ruíz et al., (2017) for the identification of cases of pigmentary anomalies in birds. The records reported here are the first of partial leucism and albinism for the Ruddy Ground-Dove in Colombia.

Leucism appears to be more prevalent in certain families of birds. However, they rarely represent more than one percent of the individuals in a natural population (Aráozet al., 2012). This frequency seems to be higher in cities, compared to the countryside, possibly because the factors that cause leucism are more common in polluted urban areas (Møller \& Mousseau, 2001). High frequencies of leucism in bird populations may also be genetically associated with inbred populations (Benschet al., 2000).

It is relevant to report cases of plumage aberrations, since they are often not published in the scientific literature, especially in the Neotropics, and this possibly leads to an underestimation of the prevalence of plumage aberrations in the tropics (Sainz-Borgo et al., 2016). Therefore, records of plumage aberrations help contribute to the knowledge of the frequency and distribution of the species with atypical colorations and their incidence in urban bird populations.

\section{Acknowledgment}

We thank E. Machado-Hernández and L. Calvert for the review and contributions that improved the final version. Also to D. Eusse-González, Information System Coordinator at Asociación Calidris for the map elaboration and to I. C. Avila for supplying the photographs of the young nestling Ruddy Ground-Dove.

\section{References}

Aráoz, R., Aveldaño, S. \& Ortiz. D. (2012). Casos de plumajes aberrantes en tres especies de aves en Tucumán, Argentina. Acta Zoológica Lilloana, 56(1-2), 159166.

Bensch, S., Hansson, B., Hasselquist, D. \& Nielsen, B. (2000). Partial albinism in a semi-isolated population of great reed warblers. Hereditas, 133, 167-170.

https:// doi.org/10.1111/j.1601-5223.2000.t01-1-00167.x

Cadena-Ortiz, H., Bahamonde-Vinueza, D., Cisneros-Heredia, D. F. \& Buitrón-Jurado, G. (2015). Alteraciones de coloración en el plumaje de aves silvestres del Ecuador. Avances en Ciencias e Ingenierías, 7(2), B75-B90.

https:/ / doi.org/10.18272/aci.v7i2.259

Davis, J. N. (2007). Color abnormalities in birds: a proposed nomenclature for birders. Birding, 39(5), $36-46$.

Fuentes, D. \& González-Acuña, D. (2011). Aberraciones cromáticas del plumaje en aves: nuevos reportes en Chile. Boletín Chileno de Ornitología, 17(2), 113-121.

Gross, A. O. (1965). The incidence of albinism in North American birds. Bird-Banding, 36(2), 67-71.

https:/ / doi.org/10.2307/4511145

Guay, P. J., Potvin, D. A. \& Robinson, R. W. (2012). Aberrations in plumage coloration in birds. Australian Field Ornithology, 29(1), 23-30.

Hernández-Valdez, S. D., Rodríguez-Maturino, J. A. \& Viggers-Carrasco, M. G. (2016). Primer reporte de leucismo parcial en el tordo cabeza café (Molothrus ater) en el estado de Durango, México. Huitzil, Revista Mexicana de Ornitología, 17(2), 239-243.

https:/ / doi.org/10.28947/hrmo.2016.17.2.253

Hilty, S. L. \& Brown, W. L. (1986). A guide to the birds of Colombia. Princeton, New Jersey. Princeton University Press. 836 pp.

McGraw, K. J., Wakamatsu, K. Ito, S., Nolan, P. M., Jouventin, P., Dobson, F. S., Austic, R. E., Safran, R. J., Siefferman, L. M., Hill, G. E. \& Parker, R. S. (2004). You can't judge a pigment by its color: carotenoid and melanin content of yellow and brown feathers in swallows, bluebirds, penguins, and domestic chickens. The Condor, 106(2), 390-395.

https:/ / doi.org/10.1093/condor/106.2.390

Meyer, R. \& Phelps, W. H. (1978). A guide to the birds of Venezuela. Princeton, New Jersey. Princeton University Press. 424 pp.

Missagia, C. C. C., Ferrão, A. C. D. J., Vecchi, M. B., Martins-Silva, J. \& Alves, M. A. S. (2016). Color aberration in a Ruddy Ground Dove Columbina talpacoti (Aves: 
Columbiformes) in a coastal island of the Brazilian Atlantic forest. Annales Zoologici Fennici, 53, 120-124. https:/ / doi.org/10.5735/086.053.0211

Møller, A. P. \& Mousseau T. A. (2001). Albinism and phenotype of Barn Swallows (Hirundo rustica) from Chernobyl. Evolution, 55(10), 2097-2104.

https:/ / doi.org/10.1111/j.0014-3820.2001.tb01324.x

Ridgely, R. S. \& Gwynne, J. A. (1989). A guide to the birds of Panama, with Costa Rica, Nicaragua and Honduras. Princeton, New Jersey. Princeton University Press. $534 \mathrm{pp}$.

Rodríguez-Ruiz, E. R., Martínez-Sánchez, I. \& Treviño-Carreón, J. (2015). Nuevos registros de aberraciones cromáticas en el plumaje de dos especies de aves en zonas urbanas de Hidalgo y Tamaulipas, México. Acta Zoológica Mexicana (Nueva Serie), 31(3), 447-450. https:// doi.org/10.21829/azm.2015.3131088

Rodríguez-Ruíz, E. R., Poot-Poot, W. A., Ruíz-Salazar, R. \& Treviño-Carreón, J. (2017). Nuevos registros de aves con anormalidad pigmentaria en México y propuesta de clave dicotómica para la identificación de casos. Huitzil Revista Mexicana de Ornitología, 18(1), 57-70.

https:/ / doi.org/10.28947/hrmo.2017.18.1.264
Sage, B. L. (1963). The incidence of albinism and melanism in British birds. British Birds, 56, 409-416.

Sainz-Borgo, C., Ascanio, D., Calcaño, L., López, E., Miranda, J., Rodríguez-Ferraro, A., Ravard, R., Santodomingo, J., Trejo, M. \& van Grouw, H. (2016). Nuevos registros de aberraciones en el plumaje para varias especies de aves en Venezuela. Revista Venezolana de Ornitología, 6, 68-73.

Urcola, M. R. (2011). Aberraciones cromáticas en aves de la colección ornitológica del Museo Argentino de Ciencias Naturales "Bernardino Rivadavia". Revista del Museo Argentino de Ciencias Naturales (Nueva Serie), 13(2), 221-228.

https:/ / doi.org/10.22179/REVMACN.13.225

van Grouw, H. (2006). Not every white bird is an albino: Sense and nonsense about color aberrations in birds. Dutch Birding, 28, 79-89.

van Grouw, H. (2013). What color is that bird? The causes and recognition of common color aberrations in birds. British Birds, 106, 17-29.

Yusti-Muñoz, A. P. \& Velandia-Perilla, J. H. (2013). Un caso de leucismo en Columbina talpacoti (Columbidae) en el Valle del Cauca, Colombia. Ornitología Colombiana, 13, 79-82. 


\section{Giovanni Cárdenas}

Asociación para el Estudio y Conservación de las Aves Acuáticas en Colombia-Calidris.

Cali, Colombia.

https:/ / orcid.org/0000-0001-5915-2816

gcardenas@calidris.org.co

Autor para correspondencia

Juan Camilo Franco

Universidad Autónoma de Occidente.

Cali, Colombia.

https:/ / orcid.org/0000-0001-8363-8314

juan_c.franco@uao.edu.co
New records of pigmentary abnormalities in two species of birds in Cali, Colombia

Citación del artículo: Cárdenas, G. \& Franco, J. C. (2021). New records of pigmentary abnormalities in two species of birds in Cali, Colombia. Biota Colombiana, 22(2), 147-154.

https:/ / doi.org/10.21068/c2021.v22n02a08

Recibido: 26 de enero 2021

Aprobado: 6 de abril 2021 